\title{
Çatışma Ve Çatışma Çözümü Sürecinde Duyguların Rolü
}

\section{ÖZET}

\section{Esra Hatice OĞUZ TAŞBAŞ ${ }^{1}$}

Değişen dünya dinamikleri ve gelişen iletişim imkanları ile çatışmalar siyaset, ekonomi, sosyoloji gibi alanlarla birlikte sosyal ve politik psikoloji çalışmaları için de odak konulardan biri haline gelmiştir. Çatışma konusunun giderek artan önemine binaen bu derleme çalışmasında çatışma, hem yıkıcı hem yapıcı yönleriyle irdelenmeye çalışılmış, duyguların çeşitli tanımları, boyutları ve bileşenlerine farklı bakış açıları ışığında değinilmiştir. Bu derleme çalışmasının ana amacı, hayatın hemen her alanında rastlanabilen çatışma olgusu ile her birey tarafından kaçınılmaz olarak deneyimlenen duygu tecrübesinin ilişkisini incelemektir. Bu çalışmada çatışma ve duygu alanyazınları genel hatlarıyla ele alındıktan sonra bu iki alanın kesişimden ortaya çıkan görgül çalışmalara yer verilmektedir. Son olarak çatışma çözümü ve müzakere süreçlerinde duyguların rolü özetlenmektedir. Bu çerçevede, çalışmanın özellikle Türkiye'de yapılabilecek çatışma çalışmaları ve müdahale programlarına yol göstermesi hedeflenmektedir.

Anahtar Kelimeler: Çatışma, çatışma çözümü, müzakere, duygular

\section{The Role Of Emotions In Conflict And Conflict Resolution}

\begin{abstract}
Conflict has been a focal subject for research in social and political psychology along with politics, economics, sociology due to the changing world dynamics. In this literature review, while considering the increasing significance of the subject, constructive and destructive aspects of conflict are addressed and various definitions, dimensions and elements of emotions are introduced. The main aim of this review is exploring the relationship between emotion which has been underscored in the conflict literature. To this end, general literatures on both conflict and emotions are reported briefly and then emprical findings at the intersection of these two fields were presented. Finally, the role of emotions in conflict resolution and negotiation processes was encapuslated. In this frame, it is intended to lead the way to future conflict studies and intervention programmes in Turkey.
\end{abstract}

Keywords: Conflict, emotions, conflict resolution, negotiation, conflict management

\section{GíRIŞ}

Çatışma kavramı her ne kadar ilk olarak etnik ya da dini gruplar arasında yaşanan çatışmaları çağrıştırsa da (İsrail-Filistin örneğinde olduğu gibi) aslında hem kişisel hem profesyonel hayatta çatışma; gruplar arası, kişiler arası ve bireysel düzeylerde benliğin farklı boyutlarıyla deneyimlenir. Çatışma, iş yerinde çalışanlar arasında gözlemlenebildiği gibi, aile içerisinde eşler arasında, ebeveyn çocuk ilişkilerinde de gözlemlenebilmektedir. Alanı bu denli geniş olan çatışma olgusunun farklı düzeylerde karşılaşılmasına paralel olarak, çatışma bir çalışma alanı olarak da farklı disiplinlerde konu edinilebilmektedir. Özellikle sosyoloji, ekonomi, politika ve hatta matematik gibi alanlarda kendine hemen her dönem yer bulan çatışma, sosyal psikoloji alanyazınında da artarak araştırılmaktadır.

${ }^{1}$ Arş. Gör., Düzce Üniversitesi Fen-Edebiyat Fakültesi, Psikoloji Bölümü, esraoguz@duzce.edu.tr 
Çatışma, her ne kadar farklı disiplinlerde çalışmalara sıklıkla konu olmuşsa da duygular bağlamında ele alınışına psikoloji alanyazınında aynı sıklıkta rastlanılmamaktadır (Jameson, Bodtker, Porch \& Jordan, 2009). Çatışmanın ortaya çıkmasında, yükselmesinde ve çözümünde rol oynayan duygular, aynı zamanda çatışmaya verilecek tepkilerin ortaya çıkmasında da etkilidir. Bir olay neticesinde beliren çatışma durumu, tecrübe edenler tarafindan duygular yoluyla anlamlandırılır. Aynı şekilde çatışmanın çözümü sürecinde olumlu ya da olumsuz tutumların oluşmasına ya da var olan tutumların değişmesine yol açan temel motivasyonlarda da duygular etkilidir. Çatışma süreçlerinin her noktasında duyguların bu denli kilit bir işlevi olmasına karşın, özellikle Türkçe psikoloji alanyazında, çatıșma ve duyguların birlikte ele alındığı çalışma sayısı yok denecek kadar az olduğu için böyle bir derleme çalışması teşebbüsünün faydalı olacağı düşünülmektedir.

Bu çerçevede amacı çatışma olgusunu duygular bağlamında irdelemek olan bu çalışmada, çatışma ve duyguların ilişkisi üzerine bir derleme yapılması amaçlanmaktadır. Bu bağlamda öncelikle çatışmanın ne olduğu farklı perspektiflerden değerlendirilecek ve sosyal psikoloji alanyazınında nasıl ele alındığı kısaca incelenecektir. Ardından duyguların alanyazındaki ele alınışı özetlenecek, "Duygu nedir?", "Duyguları oluşturan bileşenler nelerdir?", "Duyguların çeşitleri nelerdir?" gibi sorulara cevap aranacaktır. Daha sonra duyguların çatışma sürecindeki etkileşimi görgül çalışmalar ile örneklenerek incelenecektir. Son olarak çatışma çözümünde duyguların ve duygu yönetiminin rolünü kısaca özetlemek hedeflenmiştir.

\section{Çatışma Tanımları ve Çatışmanın Doğası}

Sosyal bilimler alanyazınındaki hemen her geniş kapsamlı kavram gibi çatışmanın da üzerinde tam fikir birliği sağlanmış bir tanımı yoktur. Sosyal psikoloji şüphesiz çatışmayı gruplar arası süreçler bağlamında tanımlama eğilimi gösterir ancak her araştırmacı kendi perspektifinden çatışmanın ne olduğunun sınırlarını çizer ve o sınırlar dahilinde çatışmayı değerlendirir. Rahim (1992) çatışmayı "uyuşmazlık, anlaşmazlık ya da sosyal varlıklar (bireysel, grupsal, organizasyonel gibi) içindeki ya da arasındaki farklılıkların göstergesi olan interaktif bir süreç" olarak tanımlar. Bu tanım, bireyin kendisinin çatışma yaşayabileceği hem bir özne hem de bir nesne olabileceği gerçeğini dışlamaz. Ancak yine de sosyal psikoloji alanyazınında çatışma sıklıkla karşımıza kişiler ya da gruplar arası düzeyde çıkar. Thomas (1992) çatışmayı, taraflardan birinin diğeri için önemli bir durumu engellediğini ya da engellemeye teşebbüs ettiğini düşündüğünde başlayan bir süreç olarak tarif eder ve bu durumu diğer sosyal süreçlerin (karar verme gibi) dönüştüğü bir nokta, bir başlangıç olarak görür. Putnam ve Poole (1987) bireyler ya da gruplar arasında görülen çatışmanın kaynağını, kişiler arası etkileşime ve birey ya da grupların birbirleriyle koordineli davranmaları gerektiği için karşılıklı bir bağımlılık içerisinde olmalarına bağlar. Kriesberg ve Dayton'nun kitabı Constructive Conflicts'te (2012) daha güncel bir sosyal çatışma tanımı yapılır; "iki veya daha fazla kişinin ya da grubun birbirleriyle bağdaşmayan hedeflerinin varlığına dair inançlarını gösterdiklerinde ortaya çıkan mücadelelere çatışma denir". Swanström ve Weissman (2005) çatışmanın dairesel bir yaşam döngüsü olduğunu iddia eder. Bu döngünün tekrar ettiğini ve şiddet düzeyinin artmasıyla birlikte mevcut durumun kriz ya da savaşa dönüştügünü, ardından düşüşe geçmesinin ise görece barış olarak tariflememize neden olduğunu ifade eder. Çatışmanın farklı özellik ve tezahürlerinin altını çizen bütün bu tanımların varlığına dair bilgi sahibi olmak, araştırmacıların çatışma konusunu ele alınışlarındaki çeşitliliği işaret etmesi bakımından önem teşkil etmektedir.

Çatışmanın tanımı perspektiflere göre değişse, her çatışmanın kendine özgü tarihi ve özgül nedenleri olsa da, ortaya çıkış sebepleri ve süreçleri bakımından bireysel düzlemden uluslararası düzleme dek çatışmalarda gözlemlenen bazı ortaklıklardan söz edilebilir. Bunlardan biri taraflar arasında algılanan adaletsizliktir. İster bireyler arası ister uluslar arası düzeyde olsun taraflar kendi bireysel çıkarlarını adil olan seçeneğin önüne koyabilir ya da taraflardan biri diğerinin kendi sınırlarını ihlal ettiği algısına sahip olabilir, bunun neticesinde de öfke ve suçluluk gibi duygular ortaya çıkabilir (Halevy, Kreps, Weiseş \& Goldenberg, 2015). Çatışma alanyazınında sıklıkla çatışma nedenleri arasında gösterilen bir diğer öğe de sınırlı kaynaklar için rekabet edildiği gerçeğidir. İster petrol kaynakları için savaşan ülkeler üzerine yapılmış çalışmalar olsun, ister iki birey arasında üçüncü bireyin partnerliği için ortaya çıkmış çatışma olsun, bu çatışmaların ortaya çıkmasında rol oynayan itici gücün benzerliğinden söz etmek mümkündür. Her iki durumda da taraflar limitli olarak algıladıkları kaynak için karşı karşıya gelir. Temel yükleme hatasının (fundamental attribution error), yapılan birçok çalışmada (Gifford \& 
Hine 1997, Hine \& Gifford, 1996) çatışma sürecindeki etkisinin incelendiği görülmektedir. Bu çalışmalar çatışma içerisinde olan tarafların, diğer tarafın davranışlarını değerlendirirken, davranışın kaynağını durumsal faktörlerle açıklamak yerine daha özcü yaklaşarak karşı tarafın mizacına yorduklarını göstermiştir. Temel yükleme hatasına eğilimli olunduğu koşulda, negatif durumlar gözlendiğinde bunun sebebini geçici koşullara ve dışsal faktörlere bağlamak yerine, kişinin ya da grubun kendisine bağlıyor olmak çatışmayı motive edebilir. Ortak anlayışın olmayışı, iletişim sorunları ve tarafların birbirinden beklentilerinin açık olmaması da çatışmanın ortaya çıkma sebebi olabildiği gibi sonucuna ve çatışmayı besleyen bir öğeye dönüșebilir. Çatışmayı inceleyen bilim insanlarının en sık değindikleri çatışmayı ortaya çıkartan etkenlerden ve çatışmanın sonuçlarından biri de sosyal inançlardır. Sosyal inançları Bar-Tal (2007) bir topluluğun özellikleri, yapısı ve süreçleri olarak tanımlar. Toplumsal normlar, iç grubun imajı, dış grupların imajları ile ilgili olan bu sosyal inançlar kuşkusuz çatışmanın ortaya çıkışından çözümüne kadar hemen her süreçte belirleyici rol oynamaktadır. Farklı yaklaşımlarla göre şekillenen tanımlarına rağmen çatışmanın doğası itibariyle paylaştığı ortak özelliklerinden bahsedilebilmektedir. $\mathrm{Bu}$ denli yaygın olarak hayatın içerisinde yer alan çatışma kaçınılmaz mıdır, derhal kurtulunması gereken bir sorun mu yoksa işlevsel bir araç mıdır?

\section{Çatışma İyi midir, Kötü müdür?}

Çatışma (conflict) kavramı sıklıkla, kaçınılması gereken bir karşı karşıya gelişi ima ettiğinden, çatışmanın bir an önce çözüme (resolution) kavuşturulması gerektiği düşünülmektedir. Bu sebeple çatışma tanımlarının çoğu, çatışmanın bireyler ve gruplar için olumsuzluğa yol açtığı görüşünü içerisinde barındırmaktadır (Jehn, 1997). Çatışma alanında çalışan bilim insanlarının hatırı sayılır bir kısmı bu görüşü desteklemektedir. De Dreu ve Weingart (2003) yaptıkları meta-analizde çatışmanın negatif duyguların oluşmasına yol açtığını, neticesinde grubun üyelerinin dikkatlerinin dağılmasına sebep olduğunu, kısacası grup performansı için yıkıcı sonuçlar doğurduğunu iddia etmiştir.

Öte yandan bir başka çatışma anlayışı da çatışmanın üretkenliğe ve doyuma hizmet ettiği için olumlu olarak değerlendirilebileceğini iddia etmektedir. Örneğin Tjosvold (1991) çatışma aracılığıyla problemlerin tespit edilebileceğini ve çözüm üretilerek daha adil bir ortamın yaratılabileceğini "pozitif çatışma" kavramıyla ortaya koymuştur. Pozitif çatışma kavramının altında yatan fikir, çalışanların çatışma sayesinde rahatsızlıklarını açığa vurabilecekleri ve kendilerini ifade edebilecekleridir. $\mathrm{Bu}$ şartlarda çalışanlar çatışma aracılığıyla sorunlarla başa çıkabilmekte ve böylece iş yerindeki verimlilik arttırılabilmektedir. Çatışma fenomeninin olumlu olduğu görüşünün bir diğer iddiası, gruptaki ayrışıklığın grubun verimliliğine olan katkısıdır. Bir diğer deyişle çatışma, organizasyonlarda sistemin işlemeyen yanlarını belirlemeye yarayabilmektedir. Çatışma, yöneticilere ve çalışanlara organizasyondaki ya da grup süreçlerindeki sorunları tespit etme şansı verirken, bu sorunların etkili bir biçimde yönetimi için de neler yapılabileceğini belirlemede yardımcı olduğu söylenebilir (Chaudhry \& Asif, 2015). Baron'a göre (1991) bilişsel çatışma (cognitive conflict) sayesinde alınan kararların kalitesini iyileştirme şansı yakalanmış olmaktadır.

Son yıllarda yapılan çalışmalar çatışmanın fayda ve zararlarına odaklanmaktan çok, doğru yönetilmediği takdirde oluşturabilecekleri potansiyel zararın ve çatışma çözümünde üzerinde durulması gereken noktaların altını çizmektedir.

\section{Duygu Alanyazınına Genel Bakış}

Eski Yunan Edebiyatı'nın en ünlü ve eski eserlerinden Homer'in İlyada'sının açılış kelimesi $\mu$ ñvıs (menis) yani öfkedir. Liderlerin kitleleri yönlendirmede başvurdukları yöntemlerin başında her şeyden önce kalabalıkların duygularını manipüle etmek gelir. Duygular eyleme geçmemizi ya da geçmemizi sağlayan temel unsurlardandır. Sosyal hayatın her aşamasında yansımaları olan duygular, insan varlığının devamlılığı için işlevseldir ve evrimsel psikoloji perspektifinden duygular, türün devam edebilmesi bakımından kaçınılmazdır.

Duygu denince hemen herkes neyden bahsedildiğini anladığını düşünse de duygunun ne olduğunu tanımlamakta zorlanır. Bu tanımlama güçlüğü sadece sokaktaki insan için değil alanyazında çalışan araştırmacılar için de geçerlidir. Kleinginna ve Kleinginna (1981) yaptıkları çalışmada 92 farklı duygu tanımı yapıldığını göstermişlerdir. Bununla birlikte duygu (emotion), his (feeling), duygulanım (affect), ifade (expression) gibi birbirlerinin yerine sıklıkla kullanılan kavram ve kelimeler de duygu kavramının 
tanımının sınırlarını belirsizleştirmektedir. Tanımların çokluğu ve yakın kavramlarla ayrıştırılmasının zorluğu alanda yapılan çalışmalar için zenginlik olduğu kadar duygu ile ilişkili olması muhtemel her kavramla temas ettiği alanları tartışmaya açık hale getirir.

Cannon, Britton, Lewis ve Groeneveld (1927) duygunun göz bebeği büyüklügünün değişmesi, kalp atışının hızlanması gibi yalnızca bedensel bir tepki olduğunu iddia ederken, psikoloji alanının gelişmesiyle duygu tanımı da değişmiştir. Schachter ve Singer (1962) duyguyu sadece fizyolojik uyarılma durumu olarak tanımlamakla kalmaz ve duyguyu bu uyarılma durumuna uygun biliş olarak tarifler. Günümüze yaklaştıkça duygu tanımı Cabanac'ın (2002) tanımı gibi "yüksek yoğunluklu ve şiddetli haz (ya da rahatsızlık) içerikli herhangi bir mental tecrübe"ye evrilir. Zaman içerisinde duygunun tanımındaki bu değişim aynı zamanda duygu alanındaki çalışmaların odağındaki değişim hakkında da fikir vermektedir. Bu çalışmanın sınırları bakımından alanyazındaki bütün duygu tanımları ve dolayısıyla kuramlarına göz atmanın mümkün olamayacağı aşikardır. $\mathrm{Bu}$ derleme kapsamında kapsayıcı ve güncel olması bakımından duygu tanımını "organizma için büyük önem taşıyan içsel ya da dışsal uyarıcının değerlendirilmesine tepki olarak ortaya çıkan, organizmanın birçok alt sisteminde birbirleriyle ilişkili, eşzamanlı değişiklikler oluşumu” olarak sınırlandıracağız.

Yukarıdaki farklı tanımlardan da anlaşılabileceği gibi merkeze hangi boyutun yerleştirildiğine bağlı olarak duygu olgusunun ele alınışı farklılık gösterir. Bir dönem "içsel bir his (inner feeling)" olarak görülen duygu, bir başka yaklaşım tarafından yargılara (judgement) denk görülmüştür (Frijda, 2004). Duygu, hissedenin öznel bir biçimde tecrübe ettiği bilişsel, fiziksel ve davranışsal tepkileri içeren komplike bir yapıdır (Ekman \& Davidson, 1994). Günümüzde çağdaş psikologlar, duyguyu çok bileşenli bir süreç olarak değerlendirmektedirler. Bu bileşenler davranışsal, bilişsel ve fizyolojik olarak gruplandırılabilir.

Davranışsal (behavioral) bileşen, duygunun ifade edilmesidir. Yani kelimeler, yüz ifadeleri, ses tonu, jest, mimikler ve postür aracılığıyla duygular istemli veya istemsiz olarak açığa vurulur. Frijda (2004) duyguyu anlamak için duygunun eylemle olan ilişkisini merkeze koymanın gerekli olduğu fikrini destekler ve bireylerin çatışma durumunda nasıl davranacaklarını belirleyen itici gücün motivasyonun eyleme hazırlayıcı rolü olduğu savını önerir. Kültür, normlar ve bağlam ise bu sürecin akışını belirler.

Yukarıdaki tanımda bahsi geçen duyguların alt sistemlerinin başında gelen bileşenlerden bir diğeri de duygunun, bilişsel (cognitive) bileşenidir. Lazarrus (1991) birey çevre etkileşiminin altını çizerek duygunun bir uyarıcıyı değerlendirerek duruma adapte olmaya hizmet ettiğini savunmuştur. Söz gelimi, kendisiyle ilgili olmamasına rağmen kolektif bir eylem karşısında öfke duyan kişi için bu durumun kişinin değer ve normlarına saldırı olarak algılanması yeterlidir.

Son olarak, duygunun fizyolojik bileşeni ise duygunun insan bedeninde nasıl tecrübe edildiği ile ilgilidir. Duyguyu deneyimlediğinde, bedeninde ortaya çıkan değişimleri hemen herkes hatırlayabilir; kalabalık önünde konuşurken duyulan heyecanla birlikte ellerin terlemesi, öfke hissedildiğinde kalp atışlarının hızlanması gibi. Dantzer ve Kelley (1989) duyguların bilişsel bileşenini inkar etmemekle birlikte, duygunun motor ve fizyolojik etmenlerine değinmiş, bağışıklıkla ilgili hastalıkların ortaya çıkmasında psikolojik özelliklerin ve hatta kişilik özelliklerinin rolü olabileceğinin altını çizmişlerdir. Aynı çalışmada kanser hastalarının sahip olduğu sosyal destek, apati, ruh hali gibi etmenler ile neoplastik (aşı1rı, kontrolsüz çoğalan) hücrelerin artışı arasında yakın bir ilişki bulunmuştur (Dantzer \& Kelley, 1989). Kısacası duygu deneyimiyle insan bedeni arasında birbirinden bağımsız düşünülmesi mümkün olmayan sıkı bir bağ bulunmaktadır.

Bugün psikolojinin geldiği nokta itibariyle duygu, düşünce, inanç ve bilişi birbirinden keskin bir biçimde ayırmanın mümkün olmadığını biliyoruz. Jervis (2006) bilişle duyguyu ayırmanın imkansız olduğunu duygudan tamamen arınmış saf rasyonellik muhteva eden bir insanın ya canavar olduğunu ya da böyle bir durumun mümkün olamayacağının altını çizmektedir. Lindner’a (2009) göre psikoloji alanındaki duygu araştırmaları her ne kadar son yıllara kadar hak ettiği ilgiyi görememiş olsa da, duyguları anlamak insanı anlamak için en az biliş ya da motivasyon kadar önemlidir. Duygular, aksiyona geçmek için bireyleri motive edebildiği gibi, bireylerin bazı eylemleri gerçekleştirmesine ket de vurabilir, dolayısıyla duygular davranışla pek çok açıdan oldukça yakından ilişkilidir. Bireyler ve gruplar arası iletişimde rol aldığı gibi iş yerinde de duyguların iş çıktıları üzerindeki etkisi alanyazında bir süredir araştırmacıların dikkatini çekmiştir (Bodtker \& Jameson, 2001).

Duygu alanyazınındaki en temel eğilimlerden biri, duyumsanabilecek her türlü duyguyu pozitif veya negatif olarak ayrıştırmaktır. Aşk, sevgi, mutluluk gibi olumlu duygular çiftleşme, üreme ve yavru 
bakımı gibi türün devamlılığına hizmet eden davranışlar için adaptif değer taşırken, korku, nefret, aşağılama, suçluluk, iğrenme gibi olumsuz olarak adlandırılabilecek duygular muhtemel tehlikelere karşı uyarma fonksiyonuyla bireyler riskli durumlarla karşılaştığında hayatta kalmalarına hizmet eder. Araştırmacılar tarafından ister olumlu isterse olumsuz duygular kategorisinde değerlendirilsin, duygular genel olarak insanın hayatta kalmaya devam etmesinde rol oynar.

Ortony ve Turner (1990) yaptıkları derleme çalışmasında "Duyguların temeli nedir?" sorusunu sormuş, bazı esas (ana) duyguların olduğunu savunmuş ve kuramcıların bu birincil duyguların ne olduğu konusunda fikir birliği içerisinde olmasalar dahi bu duyguların varlığı konusunda hemfikir olduklarını ortaya koymuştur. Psikolojinin erken dönemlerinde Watson (1930) birincil duyguların korku, sevgi ve hiddetten ibaret olup doğuştan geldiğini iddia ederken, görece daha yakın dönemde Ekman, Friesen ve Ellsworth (1982) temel duyguları evrensel yüz ifadelerine bakarak tespit etmeye çalışmış ve yaptıkları çalışmalar neticesinde bu duyguların altı tane (öfke, iğrenme, korku, neşe, üzüntü ve şaşkınlık) olduğunu ileri sürmüşlerdir. Bütün bu önermeler özü itibariyle duyguların evrimsel süreçte ortaya çıktıklarını varsaydığından birincil duyguların evrensel olarak deneyimlendikleri fikrini desteklemektedir.

Her ne kadar duygulardan bazıları bütün kültürlerde deneyimlense de, duyguların nasıl tecrübe edildiği ve nasıl gösterildiği kültüre, yaşanan topluma ve hatta fiziki koşullara göre değişir, dolayısıyla duyguların da çevreye uyum sağladığı unutulmamalıdır. Pennebaker, Rime ve Blankenship (1996) 26 ülkede kişilerin kendi beyan ettikleri duygusal ifadelere bakmış ve hava sıcaklığının dahi anlamlı bir yordayıcı olabildiğini tespit etmişlerdir. Van Hemert, Poortinga ve Van de Vijver (2007) duygu kültür ilişkisini inceledikleri meta-analiz çalışmalarında endüstriyel bir toplumda yaşayanlarla tarım toplumunda yaşayanların duyguların ifadesi bakımından farklılaştığını ortaya koymuşlardır. Utanç, gurur, şehvet gibi sosyal duyguların beynin sadece insana mahsus ayna nöronları bulunan "insula" adı verilen belirli bir sistemde olduğu bulunmuştur (Baumeister, 1997). Fakat insulanın hangi düzeyde, hangi uyarıcılarla karşılaşıldığında aktifleşeceği ise sosyal, kültürel ve çevresel olarak belirlenmektedir. Kısacası bu çalışmalar duygunun varlığının her kültürde gözlemlendiğini ancak ortaya konuşunun ve anlamlandırılmasının çevre tarafından yapılandırıldığını ortaya koymaktadır.

\section{Çatışma ve Çatışma Çözümünde Duygular}

Çatışma ister ev içerisinde, ister iş yerinde, isterse gruplar arasında ortaya çıksın duygular, çatışmanın hem meydana gelmesinde, hem süreç boyunca hem de çatışmanın çözümlenmesinde merkezi bir rol oynamaktadır. Duygular çatışmayı, çatışma da duyguları doğurmaktadır. Dahası, çatışma koşulları altında eğer bireyler kimliklerinin tehdit edildiğini hissederlerse duygular daha etkili hale gelmektedir. Duygulardan bağımsız bir çatışma tanımı eksik bir çatışma tanımıdır zira duygunun olmadığı yerde çatışma da görülmez demek yanlış olmaz. Öfke, engellenme, suçluluk, utanç, sempati, saygı ve korku çatışmayla ilişkili duygulardan sadece bazılarıdır (Bell \& Song, 2005).

Aynı zamanda duygular çatışma çözümü sürecine de eşlik etmektedir ve bu süreci etkileme potansiyeline de sahiptir. Çatışma çözümü çatışmanın uzlaşmayla sona ermesi anlamına gelir, ancak bu uzlaşı tarafların uzlaşma isteğine bağlıdır. Her ne kadar insanlar prensipte barış yanlısı olduklarını ifade etseler ve uzlaşı için karşılıklı tavizin kaçınılmaz olduğunu bilseler de, bu bilgi gerçek hayatta eyleme dönüşmeyebilir.

Duygular çatışma çözümü için engelleyici ya da destekleyici olabilmektedir (Halperin \& Tagar, 2017). Çatışma çözümündeki engelleyici rol oynayan duyguların başında nefret duygusu gelmektedir. Özellikle uzun süren, tarihsel bir geçmişe dayanan çatışmalarda diğer gruba duyulan uzun süreli öfke nefrete dönüşmektedir. Lindner (2014) bu tür duyguların altında, dış grubun, ait hissettiğimiz gruba kasti olarak saygısızlık yaptığını düşünmemizin yattığı fikrini öne sürer ve ekler; "Ne kadar incitilmiş hissedersek o kadar öfkeleniriz". Örneğin, Halperin (2011) İsrail - Filistin çatışması üzerine yaptığı çalışmada duyguların barış sürecinde nasıl bir rol oynadığını incelemiş, İsrailli Yahudiler 'in sahip olduğu korku, öfke, nefret gibi duyguların barış sürecinde uzlaşmayı engelleyip çatışma çözümü ile sonuçlanması hedeflenen müzakere sürecine bireylerin desteğini azalttığını göstermiştir.

Bununla birlikte Gruplararası Duygu Teorisi (Intergroup Emotions Theory) ayrımc1l1k ve benzeri gruplar arası davranışları duyguların öncüllerini ve gruplar arası ilişkiler bakımından duyguların sonuçlarını kuramlaştırmayı amaçlamaktadır (Mackie, Devos \& Smith, 2000). Diğer bir deyişle bu kurama göre bireyler bir grupla kimliklendikleri ve kimliklendikleri bu grup benliklerinin bir parçası 
haline geldiği zaman gruplar arası duyguları deneyimlerler (Smith, Seger \& Mackie, 2007). Dolayısıyla gruptaki bireylerde grupla kimliklenme düzeyi arttıkça grup temelli duygular (korku, öfke gibi) geniş kitlelerde kolektif bir biçimde gözlemlenebilir. Olumsuz duygunun çatışmayı, çatışmanın olumsuz duyguları beslediği bir sarmalda örneğin öfke özellikle grupta başkaları tarafından da tecrübe edildiğinde daha rekabetçi tepkileri körükler (Van Kleef, 2009). Yine benzer bir şekilde Allred, Mallozzi, Matsui ve Raia (1997) yaptıkları deneysel çalışmada yüksek düzeyde öfke ve düşük düzeyde sevecen duygular deneyimleyen arabulucuların gelecekte daha az işbirliği yapma ve daha az ortak hedef gerçekleştirme eğilimine sahip olduklarını göstermişlerdir.

Araştırmacılar duyguların sadece gruplar arası çatışmalarda etkisine bakmamışlar aynı zamanda evlilik ve aile içi çatışmaları da duygular çerçevesinde incelemişlerdir. Örneğin Prager (1991) olumsuz duygu göstermenin romantik partnerler arasındaki çatışma çözümünü olumsuz etkilediğini göstermiştir. İnsan da diğer hayvanlar gibi primer korkularının olmasının yanında geçirdiği sosyokültürel gelişimlerle birlikte korkuyla ilişkili gözlem yapabilme ve sözlü iletişim kurma becerisi edinmiştir. Bu da insanın daha az risk almaya çalışmasına yol açmıştır (Olsson, Nearing \& Phelps 2007). Fakat çatışmanın çözümünde korku uyandırmak, taraflara avantaj sağlamaktan ziyade yapıcı bir çözüm yolunu imkansızlaştırabilmektedir.

Her ne kadar negatif olarak adlandırılabilecek duygular çatışma çözümünün ve müzakerenin önünde engel teşkil edip yıkıcı bir etki gösterse de güven, yakınlık, umut, empati, sıcaklık gibi pozitif duygular da müzakereyi ve çatışma çözümünü destekleyici bir rol üstlenebilmektedir. Rosler, Cohen-Chen ve Halperin (2015) yaptıkları güncel bir çalışmada, çözümlenemeyen bir çatışma (intractable conflict) örneği olarak İsrail - Filistin örneğini incelemiştir. Çatışmaya yönelik tutumlarda hem empatinin hem de umut duygularının, çatışmanın yükseldiği ve düştüğü farklı dönemlerde yordayıcı oldukları bulunmuştur (Rosler vd, 2015).

$\mathrm{Bu}$ görüş çatışmanın döngüsel bir süreç olduğunu düşünen kamp ile paralel bir bakış açısı taşır. Zira çatışma tekrar eden bir döngüyse bu döngünün ilk aşamaları çatışmayı önlemek için uygun bir zamandır. Çatışmanın zirve yapışından sonraki aşama çatışma çözümü stratejilerinin uygulanması için daha uygun bir aşama olarak görülmüştür (Swanström \& Weissman, 2005). Bu bağlamda da çatışmanın doğru aşamasında destekleyici duyguların teşvik edilip çatışma çözümüne ket vurması muhtemel duyguların doğru aşamada önüne geçilmeye çalışılması müzakere ve çatışma çözümü süreçlerini besleyebilir.

Yapılan çalışmalar çatışmanın şiddetini azaltmak ya da tamamen ortadan kaldırmak için olumlu duyguları meydana çıkaran çok basit yöntemlerin kullanılabileceğini ortaya koymuştur. Baron ve meslektaşlarının (1990) yaptıkları çalışmada, mizah, hediye ya da övgü gibi son derece basit yöntemlerin olumlu duyguların ortaya çıkmasında etkili olduğunu bulmuşlardır. Bu gibi durumlarda bireylerin, olumlu duyguların etkisiyle gelecekteki çatışmaları çözme niyetlerinin daha fazla olduğu ve çatışmada rekabete daha az rağbet edildiği belirtilmiştir (Baron, Fortin, Frei, Hauver, \& Shack 1990). Pozitif duyguların birçok bilişsel ve davranışsal süreci etkilediği gibi çatışma çözüm süreçlerini etkilemektediği görülmektedir. Olumlu duygulanımın beyindeki dopamin seviyesini arttırarak yaratıcı problem çözme becerilerindeki performansın da buna paralel arttığı yapılan çalışmalarla gösterilmiştir (Ashby, Isen \& Turken, 1999). Bu bağlamda Chang (2017) üniversite öğrencileri ile yaptığ1 güncel çalışmada, duygulanımın sosyal problemlerin çözümü ile ilişkisini incelemiş ve olumlu duygulanımın arttıkça olumlu problem yöneliminin arttığını göstermiştir. Aynı çalışmada, olumlu duygulanımın rasyonel problem çözmeyi de yordadığı gözlenmiştir (Chang, 2017).

Ayrıca çözümlenemez çatışmalar için çözüm desteği nasıl sağlanabilir sorusunun yanıtını arayan araştırmacılar çatışma çözüm sürecinde umut duygusunun ikna edici mesajların aktarımı için bir araç olarak kullanılabileceğini öne sürmüsslerdir (Cohen-Chen, Crisp \& Halperin, 2017). Yine bu doğrultuda Carnevale ve Isen (1986) çalışmalarında yüz yüze müzakerelerde olumlu duyguların işbirliğini arttırıp yapıcı pazarlığa olanak sağladığını ve kavgacı taktiklerin azaldığını ortaya çıkarmışlardır. Aynı doğrultuda Baron ve diğerleri (1990) yaptıkları çalışmada çatışmanın organizasyonda çözümlenebilmesi üzerinde olumlu ruh halinin etkisini incelemişler ve ruh hallerinin organizasyondaki birçok süreçte etkili olmasına paralel olarak, sosyal sebeplerle ortaya çıkan pozitif ruh hallerinin organizasyonel çatışma yönetimi stratejilerini destekleme eğiliminde olduğunu göstermiştir.

Tüm bunların yanında, yapılan çalışmaların sonuçları çatışma çözümü süreçlerinde duyguların ifade edilmesinin ve düzenlenmesinin de önemli olduğunu göstermiştir. Her iki duygu grubunu (pozitif ve negatif) ifade edebilen ve bu duyguları düzenleyebilen tarafların müzakerenin seyrinde ve sonuçlarında 
daha etkili oldukları bulunmuştur (Curşeu, Boroş \& Oerlemans, 2012). Bununla birlikte olumlu duygulara karşı bir yanlılık olduğu söylenebilir. Kopelman, Rosette ve Thompson (2006) yaptıkları deneylerde müzakerecilerin negatif ya da nötral duygular yerine olumlu duygular gösterdiklerinde daha fazla başarı elde ettiklerini ortaya koymuşlardır. Halperin ve Tagar (2017) duyguların gruplar arası çatışmalarla, çatışma yönetimi ve çözümüyle ilgili kamu desteğini güçlendirici etkisi olduğunu ortaya koymuştur. Duyguların yol açtığı bu etki, kendini sadece grup düzeyinde değil aynı zamanda birey düzeyinde de gösterererk çatışma çözümünün en önemli adımlarından biri olan "temas" için de itici bir güç olabilir (Halperin \& Tagar, 2017).

Çatışma çözümü ve müzakere süreçlerinde sadece hangi duyguya sahip olunduğu ya da duygunun valansı önemli değildir, duyguların nasıl düzenlendiği de bu süreçlerde etkilidir. Gross (1998) duygu düzenlemeyi; hangi duyguları, ne zaman, nasıl tecrübe edeceğimizi ve bu duyguları nasıl ifade edeceğimizi yöneten süreçler olarak tanımlar. Diğer bir deyişle duygu düzenleme, duygunun nasıl tecrübe edileceğinin idare edilmesidir. Matsumo, Yoo ve LeRoux (2009) kültürel farklardan doğabilecek çatışmalarla başa çıkarken bazı psikolojik becerilere sahip olmanın gerektiğini ileri sürmüşler ve bu becerilere "adaptasyon ve uyumun psikolojik motoru" ismini vermişlerdir. Ayrıca bu "motoru" formülüze ederken kişisel gelişimin muhtevasını Duygu Düzenleme (Emotion Regulation), Eleştirel Düşünme (Critical Thinking), Açıklık (Openness) ve Esneklik (Flexibility) olarak tanımlamışlardır. Kısacası tarafların duygularını düzenleme yetileri çatışma ve çatışma çözümü süreçlerinde oldukça hayati bir rol oynamaktadır.

Sonuç olarak alanyazın duygu ve çatışma ilişkisini değerlendirirken ikiye ayrılmaktadır. Alanyazının büyük bir kısmı duyguların tecrübe edilmesine odaklanırken, son yıllarda yapılan birçok çalışma duyguların ifade edilmesinin çatışma üzerinde gösterdiği etkinin altını çizmeyi amaç edinmiştir. Örneğin Solak, Reifen Tagar, Cohen - Cohen, Saguy ve Halperin (2017) İsrail-Filistin çatışmasında ve Siyahi ile Beyaz Amerikalılar arasındaki çatışmada, İsrailli Yahudilere ve Amerikalı Beyazlara dış gruplarının duygu ifadeleri ile ilgili bilgi verilmiş ve bunun neticesinde dış grubun hayal kırıklı̆̆ bilgisi verilenlerin diğerlerine kıyasla daha fazla kolektif suçluluk duygusuna sahip oldukları ve kolektif eylemleri daha fazla destekleme eğilimi gösterdiklerini bulgulamışlardır.

\section{SONUC}

Çatışma birbirinden çok ayrık gibi görünen disiplinlerin konusu olagelse de araştırmaların sayıca büyük bir kısmı çatışma örneklerine, çatışma sebeplerine, çatışma çeşitlerine, aşamalarına ve çatışma yönetimine odaklanmıştır. Farklı çatışma kavramlaştırmaları alanyazında yapılan çalışmalardaki çeşitliliğe neden olmaktadır. Bir diğer taraftan duygu alanyazını incelendiğinde ise çok geniş bir yelpazedeki araştırma konuları arasında çatışmaya çok sık rastlanılamamaktadır. Özellikle Türkiye'de çatışma ve duyguların kesiştiği akademik çalışma sayısı ne yazık ki çok sınırlıdır. Ancak çatışma çalışmalarında duygunın varlığını gözden kaçırmak çatışma süreçlerini tam anlamıyla kavramanın önünde engel teşkil etmektedir (Jones, 2000)

Bu derlemede, çeşitli tanımları ve yaklaşımları çerçevesinde çatışma kavramının kısaca irdelenmesinin ardından, duygu alanyazınına ana hatlarıyla bir giriş yapılmaya çalışıımıştır. Çalışmanın asıl hedef zemini olan duygularla çatışmanın ilişkisinin açımlanması amaçlanmıştır. Buna ilave olarak, çatışma çözüm ve müzakere süreçlerinde olumlu ve olumsuz çeşitli duyguların muhtemel etkilerine kısaca değinilmiştir.

Çatışma ve duygu alanyazını beklenebileceği gibi ayrı ayrı olarak oldukça zengin ve uzun geçmişi olan alanlardır. Hem çatışma alanında çalışan araştırmacıların duyguların çatışma süreçlerinde oynadığı rollere daha fazla eğilmesi hem de duygu alanı uzmanlarının çatışmayla ilgili oluşumlara kayıtsız kalmaması bu iki ayrık gibi görünen ama ortaklığından fayda sağlanabilecek alanda verimli araştırmalar yapılmasına olanak sağlayacaktır. Gelecekteki çalışmaların, duyguları sadece bir arabulucu değişken olarak görmekten çok çatışmanın genel çerçevesini çizen bir olgu olarak ele almasının fayda sağlayacağı düşünülmektedir (Nair, 2008).

Çatışma her ne kadar genellikle olumsuz olarak değerlendirilse de yapılan görgül çalışmalarla çatışmaların bireyler, gruplar, organizasyonlar ve son olarak toplumlar için faydalı ve yapıcı olabileceğini görmekteyiz. Chaudhry ve Asif (2015) yaptıkları çalışmada, organizasyonda ortaya çıkan her çatışmanın yıkıcı etkileri olmak zorunda olmadığını, duyguların anlaşılması ve çözüm 
potansiyelinin farkındalığı sayesinde üretkenlikteki muhtemel düşüşün önüne geçilebiliciğini göstermiştir.

Göçler, savaşlar ve post modern dinamiklerle çatışmanın arttığı bir çağda çatışmayı daha iyi anlamak ve muhtemel çözüm yolları üretebilmek için, bireyleirn çatışma süreçlerinde deneyimledikleri duyguları anlamanın önemli olduğu görülmektedir. İşte bu yüzden bu çalışmanın hem alandaki bilim insanlarına, hem yöneticilere, hem de sahadaki müdahale programı hazırlayıcı ve uygulayıcılarına fikir verebilmesi hedeflenmiştir. Gelecekte çatışma alanında yapılacak çalışmalar ve müdahale programları duyguları sadece bir yan ürün, görmezden gelinebilir bir çıktı olarak ele almaktan ziyade, duyguların hem çatışmanın ortaya çıkma sebebi hem de çözümün parçası olabileceğini göz önünde bulundurmalıdır. Çünkü çatışma temel olarak duygusal olarak ortaya çıkar ve duygular tarafından yönetilir (Bodtker \& Jameson, 2001). Lindner'ın (2014) da ifade ettiği gibi "çatışma ve duygular hem problemin aslı hem de çözümüdür".

Bu çalışma ile Türkiye'de ve dünyada yapılacak çalışmalara bir zemin oluşturması amaçlanmaktadır. Çatışma, müzakere ve çözüm süreçlerinde, duygu ve duygu düzenlemesini daha iyi anlamak sadece bilimsel ilerlemeye değil sosyal barışa da hizmet etmesi bakımından yarar sağlayacaktır.

\section{KAYNAKLAR}

Allred K. G., Mallozzi JS, Matsui F, Raia CP. (1997). The influence of anger and compassion on negotiation performance. Organizational Behaviour and Human Decision Process. 70(3), 175-87. https://doi.org/10.1006/obhd.1997.2705

Ashby, F. G., Isen, A. M., \& Turken, A. U. (1999). A neuropsychological theory of positive affect and its influence on cognition. Psychological Review, 106, 529 -550. DOI: 10.1037/0033-295X.106.3.529

Baron, R. A. (1991). Positive effects of conflict: A cognitive perspective. Employees Responsibilities and Rights Journal, 4, 25 -36

Baron, R. A., Fortin, S. P., Frei, R. L., Hauver, L. A. \& Shack, M. L (1990). Reducing organizational conflict: the role of socially-induced positive affect. International Journal of Conflict Management. 1 (2), 133-152. DOI: 10.1108/eb022677

Bar-Tal, D. (2007). Sociopsychological Foundations of Intractable Conflicts. American Behavioral Scientist, 50, 1430-1453. https://doi.org/10.1177/0002764207302462

Baumeister, R. F. (1997). Evil: Inside human cruelty and violence. New York: W.H. Freeman.

Bell, C., \& Song, F. (2005). Emotions in the conflict process: An application of the cognitive appraisal model of emotions to conflict management. International Journal of Conflict Management, 16(1): 3054. DOI: $10.1108 / \mathrm{eb} 022922$

Bodtker, A.M. \& Jameson, J.K. (2001). Emotion in Conflict Formation and its Transformation: Application to Organizational Conflict Management, International Journal of Conflict Management, 12(3), 259-275

Cabanac M. (2002). What is emotion? Behavioural Processes. 60, 69-84. http://dx.doi.org/10.1016/S0376-6357(02)00078-5

Carnevale, P. J. D. \& Isen, A. M. (1986). The influence of positive affect and visual access on the discovery of integrative solutions in bilateral negotiation. Organizational Behavior and Human Decision Processes, 37, 1-13

Cannon, W. B., Britton, S. W., Lewis, J. T.,\& Groeneveld, A. (1927). Studies on the conditions of activity in endocrine glands. American Journal of Physiology-Legacy Content, 79(2), 433-465. doi:10.1152/ajplegacy.1927.79.2.433 
Chaudhry, A. M. \& Asif, R. (2015). Organizational Conflict and Conflict Management: a synthesis of literature. Journal of Business and Management Research, 9, 238-244.

Cohen-Chen, S., Crisp, R. J. \& Halperin, E. (2017). Hope comes in many forms: Outgroup expressions of hope override low support and promote reconciliation in conflicts. Social Psychological and Personality Science, 8, 153-161.

Curşeu, P. L., Boros, S. \& Oerlemans, L. A. G. (2012). Task and relationship conflict in short-term and long-term groups: The critical role of emotion regulation. International Journal of Conflict Management, 23, 97-107. https://doi.org/10.1108/10444061211199331

Dantzer, R. \& Kelley, K. W. (1989) Stress and immunity: an integrated view of relationships between the brain and the immune s ystem. Life Science, 44, 1995-2008

De Dreu, C.K.W. \& Weingart, L.R. (2003). Task versus relationship conflict, team performance, and team member satisfaction: a meta-analysis. Journal of Applied Psychology, 88(4), 741-749.

Ekman, P. (1994). All Emotions Are Basic, P. Ekman, P. \& R. Davidson (Ed.) içinde, The Nature of Emotion: Fundamental Questions (s. 15-19). New York: Oxford University Press.

Ekman, P., Friesen, W. V. \& Ellsworth, P. (1982). What emotion categories or dimensions can observers judge from facial behavior, P. Ekman (Ed.) içinde, Emotion in the human face (s. 39-55). New York: Cambridge University Press.

Frijda, N. H. (2004). Emotion and action. A. S. R. Manstead, N. Frijda, \& A. Fischer (Ed.) içinde, Feelings and emotions: The Amsterdam symposium (s. 158-173). Cambridge, England: Cambridge University Press

Gifford, R. \& Hine, D. W. (1997). Toward cooperation in commons dilemmas. Canadian Journal of Behavioural Science / Revue canadienne des sciences du comportement, 29(3), 167-179.

Gross, J. J. (1998). The emerging field of emotion regulation: An integrative review. Review of General Psychology, 2, 271-299

Halevy, N., Kreps, T. A., Weisel, O. \& Goldenberg, A. (2015). Morality in intergroup conflict. Current Opinion in Psychology, 6, 10-14.

Halperin, E. (2011). Emotional barriers to peace: Emotions and public opinion of Jewish Israelis about the peace process in the Middle East. Peace and Conflict: Journal of Peace Psychology, 17(1), 22-45.

Halperin, E. \& Reifen-Tagar, M. (2017). Emotions in conflicts: Understanding emotional processes sheds light on the nature and potential resolution of intractable conflicts. Current Opinion in Psychology, 17, 94-94. https://doi.org/10.1016/j.copsyc.2017.06.017

Hine, D.W. \& Gifford, R. (1996a). Attributions about self and others in commons dilemmas. European Journal of Social Psychology, 26, 429-445

Jameson, J. K., Bodtker, A. M., Porch, D. M., \& Jordan, W. J. (2009). Exploring the role of emotion in conflict transformation. Conflict Resolution Quarterly, 27(2), 167-192. https://doi.org/10.1002/crq.254

Jervis, R. (2006) Understanding Beliefs. Political Psychology, 27 (5), 641-805.

Jones, T. S. (2000). Emotional communication in conflict: Essence and impact. W. Eadie \& P. Nelson (Eds.) içinde, The language of conflict and resolution (s. 81-104). Thousand Oaks, CA: Sage 
Kleinginna, P.R. \& Kleinginna, A. M. (1981). A categorized list of emotion definitions, with suggestions for a consensual definition, Motivation and Emotion, 5, 345-379. http://dx.doi.org/10.1007/BF00992553

Kopelman, S., Rosette, A.S., \& Thompson, L. (2006). The three faces of Eve: Strategic displays of positive, negative, and neutral emotions in negotiations. Organizational Behavior and Human Decision Processes, 99(1), 81- 101. https://doi.org/10.1016/j.obhdp.2005.08.003

Kriesberg, L. \& Dayton, B.W. (2012). Constructive Conflicts (4th ed.). Lanham, MD: Rowman \& Littlefield.

Lazarrus, R. S. (1991). Progress on a cognitive-motivational-relational theory of emotion. American Psychologist, 46, 819-834. DOI: 10.1037/0003-066X.46.8.819

Lindner, E. G. (2009). Emotion and Conflict: How Human Rights Can Dignify Emotion and Help Us Wage Good Conflict. Westport, CT: Praeger

Lindner, E. G. (2014). Emotion and Conflict: Why It Is Important to Understand How Emotions Affect Conflict and How Conflict Affects Emotions. M. Deutsch, P. T. Coleman \& E. C. Marcus(Ed.) içinde, The Handbook of Conflict Resolution: Theory and Practice. Third edition, San Francisco, CA: JosseyBass.

Mackie, D. M., Devos, T., \& Smith, E. R. (2000). Intergroup emotions: Explaining offensive action tendencies in an intergroup context. Journal of Personality and Social Psychology, 79, 602-616. doi:10.1037/0022-3514.79.4.602

Matsumo, D. \& Yoo, S.H. \& LeRoux, J.A. (2009). Emotion and intercultural adjustment. Intercultural communication, 7, 77-98.

Nair, N. (2008). Towards understanding the role of emotions in conflict: a review and future directions. International Journal of Conflict Management, 19, 4, 359-81.

Olsson, A., Nearing, K. I. \& Phelps, E. A. (2007). Learning fears by observing others: the neural systems of social fear transmission. Social Cognitive and Affective Neuroscience Advance Access, 2, 311

Ortony, A. \& Turner, T. J. (1990). What's basic about basic emotions? Psychological Review, 97, 315331

Pennebaker, J. W., Rime', B., \& Blankenship, V. E. (1996). Stereotypes of emotional expressiveness of Northerners and Southerners: A cross-cultural test of Montesquieu's hypotheses. Journal of Personality and Social Psychology, 70, 372-380.

Prager, K. J. (1991). Intimacy status and couple conflict resolution. Journal of Social and Personal Relationships, 8, 505-526.

Putnam, L. L, \& Poole, M. S. (1987). Conflict and negotiation. F. M. Jablin, L. L. Putnam, K. H. Roberts, \& L. W. Porter (Ed) içinde. Handbook of organizational communication (s.549-599). Newbury Park, CA: Sage.

Rahim, A.M. (1992). Managing conflict in organizations, (2nd. Ed.). Westport, CT: Praeger Publishers

Rosler, N., Cohen-Chen, S., \& Halperin, E. (2017). The distinctive effects of empathy and hope in intractable conflicts. Journal of Conflict Resolution, 6, 114-139. 
Schachter, S., \& Singer, J. (1962). Cognitive, social, and physiological determinants of emotional state. Psychological Review, 69(5), 379-399.

Smith, E. R., Seger, C. R. \& Mackie, D. M. (2007). Can emotions be truly group level? Evidence for four conceptual criteria. Journal of Personality and Social Psychology, 93, 431-446. doi:10.1037/0022-3514.93.3.431

Solak, N., Reifen Tagar, M., Cohen-Chen, S., Saguy, T., \& Halperin, E. (2016). Disappointment expression evokes collective guilt and collective action in intergroup conflict: the moderating role of legitimacy perceptions. Cognition and Emotion, 31(6), 1112-1126.

Swanström, N. \&Weissmann, M. (2005). Conflict, conflict prevention and conflict management and beyond: a conceptual exploration. Central Asia-Caucasus Institute \& Slik Road Studies Program

Thomas, K. W. (1992). Conflict and Conflict Management: Reflections and Update. Journal of Organizational Behavior, 13, 265-274.

Tjosvold, D. (1991). Rights and responsibilities of dissent: Cooperative conflict. Employee Responsibilities and Rights Journal, 4(1), 13-23.

Van Hemert, D. A., Poortinga, Y. H., \& Van de Vijver, F. J. R. (2007). Emotion and culture. A meta-analysis. Cognition and Emotion, 21, 913-943.

Van Kleef, G. A. (2009). How emotions regulate social life. Current Directions in Psychological Science, 18, 184-188.

Watson, J. B. (1930). Behaviorism. Chicago: University of Chicago Press 